\section{ART OF BOYCHUKIST ONUFRIY BIZYUKOV 1960-TH. REVIVAL OF EXPERIMENT}

\author{
Volodymyr Petrashyk, \\ https://orcid.org/0000-0001-5407-9357 \\ $\mathrm{PhD}$ in Arts, Associate Professor, \\ Kyiv National University \\ of Culture and Arts, \\ Kyiv, Ukraine \\ petrashyk.v@gmail.com
}

\author{
МИСТЕЦТВО БОЙЧУКІСТА \\ ОНУФРІЯ БІЗЮКОВА 1960-Х РР. \\ ВІДРОДЖЕННЯ ЕКСПЕРИМЕНТУ

\section{Петрашик Володимир Ігорович,} \\ https://orcid.org/0000-0001-5407-9357 \\ кандидат мистецтвознавства, доцент, \\ Київський національний університет \\ культури і мистецтв, \\ Київ, Україна \\ petrashyk.v@gmail.com
}

\begin{abstract}
The aim of the research is to highlight the tendency of the artist-boychukist Onufriy Bizyukov's work of the 1960s. To analyze the artistic and stylistic works of the artist of this period, to reveal aspects of the revival of the ideas of Boychukism at this time. Research methodology. Methods of historical and art-study analysis are used. Scientific novelty. For the first time, the facts about the life and work of the boychukist Onufriya Bizyukova were introduced into scientific circulation, the analysis of the paintings of the artist of the 1960s, the tendency to experiment in the perspective of the ideas of Boychukizm was revealed. Conclusions. As a result of the research, it was found out that O. Byzyukov used postcurrency techniques, experimented with the plane and color in the 1960s. In the works the artist focuses on the composition, structure, rhythm, form and their correspondence to the content. The most important is that the artist managed to preserve, develop and transfer the traditions of the school of Michael Boychuk for future generations in the second half of the twentieth century.
\end{abstract}

Key words:

bochukizm, experiment, plane, constructive decision, still life, postcubism, psychological sketch, decorative form, texture, geometrization, landscape, nude.

\section{Анотація}

Мета дослідження - висвітлити тенденцію творчості художника-бойчукіста Онуфрія Бізюкова 1960-х років. Проаналізувати художньо-стилістичні твори митця цього періоду, виявити аспекти відродженння ідей бойчукізму в цей час. Методологія дослідження. Використано методи історичного і мистецтвознавчого аналізу. Наукова новизна.Вперше введено до наукового обігу факти з життя і творчості бойчукіста Онуфрія Бізюкова, проаналізовані полотна художника 1960-х років, виявлено схильність до експерименту у ракурсі ідей бойчукізму. Висновки. У результаті проведеного дослідження з'ясовано, що О. Бізюков застосовував прийоми посткубізму, експериментував з площиною та кольором у період 1960-х років. У творах художник звертає особливу увагу на композицію, конструкцію, ритміку, форму та їх відповідність до змісту. Найважливіше те, що митець зумів зберегти, розвинути і передати традиції школи Михайла Бойчука для майбутніх поколінь у другій половині XX століття.

\section{Ключові слова:}

бойчукізм, експеримент, площинність, конструктивне рішення, натюрморт, посткубізм, психологічний етюд, декоративність форми, фактурність, геометризація, пейзаж, ню. 
Вступ 1 Досі не опубліковано глибокого і докладного наукового дослідження, присвяченого бойчукізму, де виявлялося б справжне значення цього мистецького напрямку як явища художньої культури XX століття та було б ретельно проаналізовано творчість представників школи Михайла Бойчука. Одним з яскравих представників цієї школи є Онуфрій Бізюков (1897-1986).

Онуфрій Терентійович Бізюков - художник-бойчукіст, що на початках своєї творчості сповідував авангардизм, майстер фрески, відомий пейзажист, портретист, митець, що звертався у своєму малярстві також і до натюрморту. Художник працював у стилях імпресіонізму, посткубізму, займався питаннями теорії мистецтва й намагався застосувати засади бойчукізму за нових умов (періоду кін. 1950-х - 1960-х рр.), експериментував з кольором.

\section{Мета дослідження}

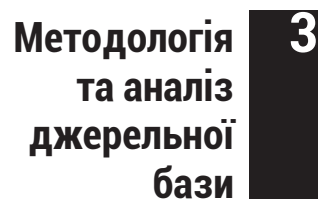

Висвітлити тенденцію творчості художника-бойчукіста Онуфрія Бізюкова 1960-х років. Проаналізувати художньо-стилістичні твори митця цього періоду, виявити аспекти відродженння ідей бойчукізму в цей час.

У ході наукового дослідження використано методи історичного і мистецтвознавчого аналізу.

Як уже говорилося, О. Бізюков пробував себе у різноманітних жанрах. Він - майстер психологічного етюду. Наприклад, жіночий портрет - це завершений твір, психологічно витончений, робота цілком у традиціях, можна сказати, художників-передвижників. Онуфрій Терентійович аскетичніше підходить до вирішення живописних завдань.

Період творчості з 1950 по 1960-ті рр. характеризується чималою серією невеликих пейзажів, таких як «Влітку» (1956), «Дніпро і кручі» (1957), «Вид на Дніпро» (1960-ті), «Київ. Міст» (1960-ті), «Дніпровські піски» (1963), «Тарасова гора» (1963) та низкою інших, що нагадують тонкою пластикою творчість художників «набідів», наприклад, П. Боннара чи Ж. Е. Вюйяра.

Це об'єднання виникло у 1888 році в Парижі і вважається оригінальним та самобутнім художнім явищем на перехідній межі пізнього імпресіонізму, але ж фахівцями відноситься до постімпресіонізму. О. Бізюков запозичив від них прийом локалізації кольору та деякої спрощеності малюнка. Крім того, художник наслідував площинність у вирішенні полотна, декоративну узагальненість форми та гармонію ритмів. Увага художника була заполонена більше формою, аніж самим змістом.

\footnotetext{
Результати дослідження

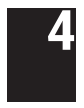

Так само, як і набідам, Онуфрію Терентійовичу властиве почуття високої пластичності. Глибока чутливість автора відчувається особливо в літніх пейзажах. Зокрема, в пейзажі «Дніпровські піски» (1963) художник працює за моделлю колірного відчуття та системою знань про нього. На картоні він кладе зелені й фіолетові мазки за головним принципом постімпре- 
Деміург: ідеї, технології, перспективи дизайну № 2 (2018)

Demiurge: ideas, technologies, perspectives of design № 2 (2018)

сіонізму, не змішуючи їх на палітрі. Бізюков моделює схему колориту за таким розташуванням головних плям блакитного і жовтого, а також зеленого й фіолетового, які б відповідно утворювали ніжний сірий і перламутровий тони. Бажаного ефекту він досягає за допомогою покладених поруч локальних барвистих мазків, які поступово переходять один в інший, у кінцевому результаті зливаючись.

Яскравий колір настільки згармонійовано в просторі, що піски на першому плані картини здаються сліпучо білими або блідо-жовтими. Водночас на другому плані - так само глибокими пісковими смугами піску простягаються берегові лінії, в яких відчутна глибина. Сіра тінь лягає з точністю, так само цільно лежить і жовта, спрямована в глибину. Найскладніше написаними тут $є$ піски, але як вони лежать, як виглядають у глибині і як відтворюють світлові контрасти! У «Дніпровських пісках» розташування усіх композиційних елементів продумане до деталей. В цьому й полягає висока мистецька майстерність автора.

О. Бізюков часто простий сюжет висловлює високохудожньою мовою. Через, здавалося б, банальний мотив художнику вдається висловити могутній образ і вирішити велике художнє завдання. Варто сказати і про багатство колористики: білий, помаранчевий, фіолетовий, блакитний, жовтий... Виникають асоціації з декоративно наснаженими краєвидами В. Кричевського, М. Бурачека, М. Ткаченка, П. Ковжуна й ін.

Пейзажі Бізюкова апелюють до традицій жанру українського краєвиду перших десятиліть XX століття. В цей час завдяки творчості яскравих представників національної пейзажної школи, цей жанр, в його стилістичних варіаціях, композиційних та колірних знахідках піднісся до рівня європейської малярської культури і став явищем в українському мистецтві, справивши значний вплив на розвиток пейзажу в подальші десятиліття.

Творчі досягнення художника зумовлені тим, що ми маємо справу з талановитим, досвідченим, інтелігентним, філософськи налаштованим глибоко мислячим митцем, чиї людські характеристики з всеосяжною повноцінністю втілились у його творчості. Адже, не маючи особистого щастя, якоїсь іншої зайнятості поза фаховими інтересами, Бізюков себе усього сповна віддавав мистецтву протягом усього життя.

Онуфрій Терентійович був залюблений у книги, бібліотека у нього добірна, що говорить про його високу культуру, особистий витончений смак. Між іншим, книжки часто стають головними героями його натюрмортів, відіграють вагому роль на автопортретах. У натюрморті «Книги» (1959-1969) з колекції Запорізького художнього музею відчувається, що на мистецькій свідомості Бізюкова позначилися ідеї авангардного живопису, ідеали новітніх пластичних форм. Це поступово наближало художника до прийомів мінімалізму, сприяло схильності до медитативного і споглядального мислення. 
Свідомо окресливши свій пошук рамками образотворчих можливостей кольору, митець спрямовує зусилля на вивчення його виражальних засобів. Бізюков упевнений: «...колір - це вже ідея, сюжет, він має самоцінність... Якщо чітко вирішено завдання, тобто правильно розміщено і визначено колірне середовище, колір, як живописна структура, здатний говорити сам» (Разінкіна, 2002, с. 24). Митець намагається виявляти національне живописно-образними моделями, в яких присутні традиційні поняття декоративності, знакової умовності, символіка кольору, метафора.

Так, і в низці інших своїх творів 1960-х рр. Бізюков оперує переважно площиною, ідеалом пластичних рішень вважає стародавню українську ікону. Автор малює на полотні, але товщина фарбового нашарування надає живописно-площинній поверхні активно визначений об'єм. Митець знайшов певну фактурну технологію, яка максимально здатна підтримати його ідеї щодо створення пристрасних й логічно-спрямованих композицій. Приваблює художника і модифікація простих форм, їхня знакова архаїка. Яскравим свідченням є картина «Архетип традиції» (1960-ті), де знак - певна архаїчна субстанція, інформативно самодостатня. Знак у Бізюкова, - своєрідна міфологема, матриця медитативних відчуттів, об'єкт «археологічної» цінності (Рис. 4.1).

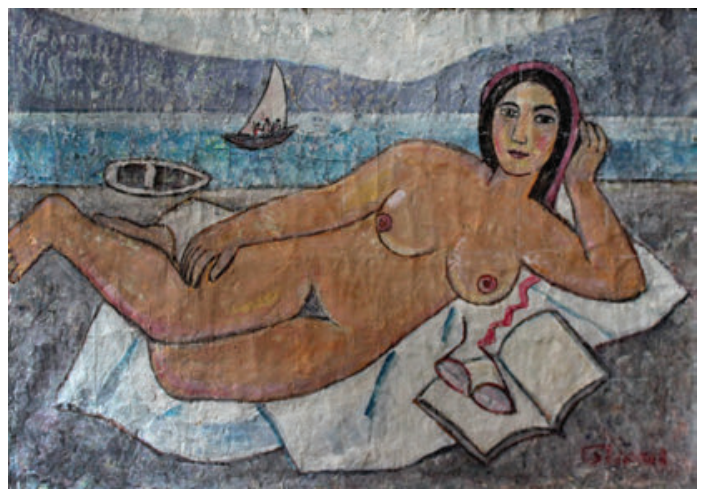

Рис. 4. 1. Онуфрій Бізюков. Архетип традиції, 1960-ті. Полотно, темпера.

Fig. 4.1. Onufriy Bizyukov. Archetype of tradition, 1960-s. Canvas, tempera.

Малярство художника останніх років розвиває та синтезує пошуки 1920-х. Творчий арсенал Бізюкова збагачують своєрідні посткубістичні й різноманітні геометричні ремікси українського модернізму початку минулого століття. Тим самим фактично було досягнуто безсюжетної образотворчої ідеї, знайдено власний асоціативний підтекст кожному твору, активну естетичну та емоційну виразність, що яскраво проявилось у творі «Ритми голосників» (1962). Тяжіння до певної анонімності, знакової метафори і символу зближує його живопис з історичними прикметами монументального мистецтва. Формальний вимір умовності у творах Онуфрія Бізюкова звучить реально вираженою естетикою, яка так чи інакше, прямо чи опосередковано впливає на мистецьку свідомість нашого часу (Рис. 4.2). 
Деміург: ідеї, технології, перспективи дизайну № 2 (2018)

Demiurge: ideas, technologies, perspectives of design № 2 (2018)

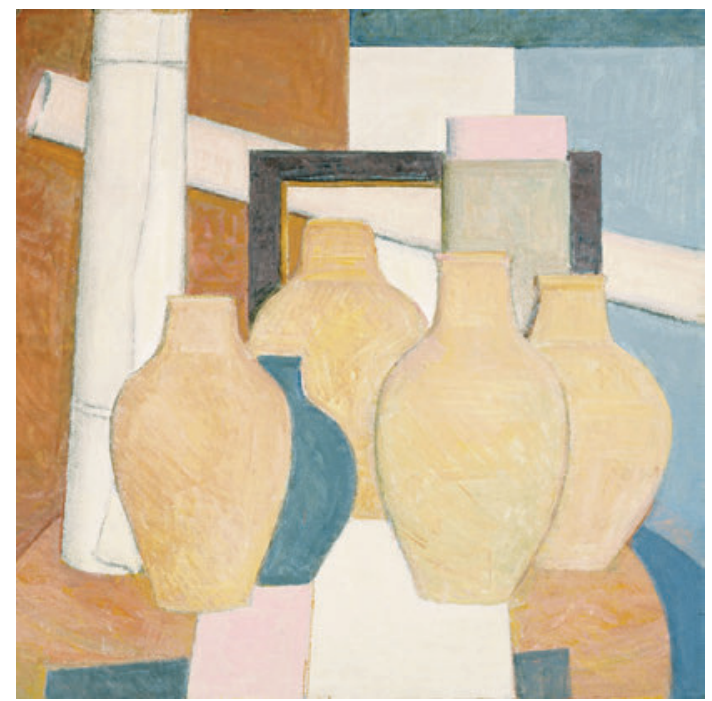

Рис. 4.2. Онуфрій Бізюков. Ритми голосників, 1962. Картон, олія. ЖС 1628. Національний художній музей України.

Fig. 4.2. Onufriy Bizyukov. Rhythms of the Voters, 1962. Cardboard, oil. ZhS 1628. National Art Museum of Ukraine.

У «Натюрморті на круглому столі» (1960-ті) предмет, форма піднесені у художника на рівень явища. Литі об'єми і разом з тим жорсткі, тверді дотики; плоть світу, яка підпорядковується двовимірності полотна. Лінія може зігнутися. І разом з нею форма потече бетонною стрічкою з рівномірними чергуваннями світла й тіні. Узагальнені, нерідко напівабстраткні явища на полотні почасти зберігають матеріальний баласт. Більше того, ніби знемагаючи від ваги матерії, прагнуть до чистоти геометрії і в цьому прагненні набувають химерності. Ваговитість і легкість - одночасно.

Предметність тут зовсім не в тому, що зображення повторює зовнішній вигляд речей: картина, як уже мовилось, може бути й абстрактною. Предметність у цьому натюрморті $€$ певною першоосновою, з якої твориться (і на якій тримається) його індивідуальний світ.

Малярство Бізюкова предметне: до того ж, ніби у двох значеннях слова: по-перше, предметність виступає як риса світовідчуття, як особливе відчуття форми; по-друге, як прагнення дійти до суті явища, визначити предмет. У «Натюрморті на круглому столі» - невелика кількість предметів організовується в єдину композиційно врівноважену групу. У непорушності форми вбачається якесь загадкове, зосереджене в собі життя. Енергія цього малярства спрямована не назовні, а вглиб. Колір тут слугує одвічною якістю предмета, а не грою швидкоплинності. Потік світла зупинений. Форма ніби вміщена у вічність, де і застигає. Час опредмечується.

У Бізюкова внутрішній рух досягається суто ритмічно: його кращі твори цього часу побудовано так, що можуть слугувати ніби посібником з композиції. Світи Бізюкова спрямовані кудись за межі осяжного. Не пейзажі і натюрморти, а наче метафізичний ландшафт (Рис. 4.3). 


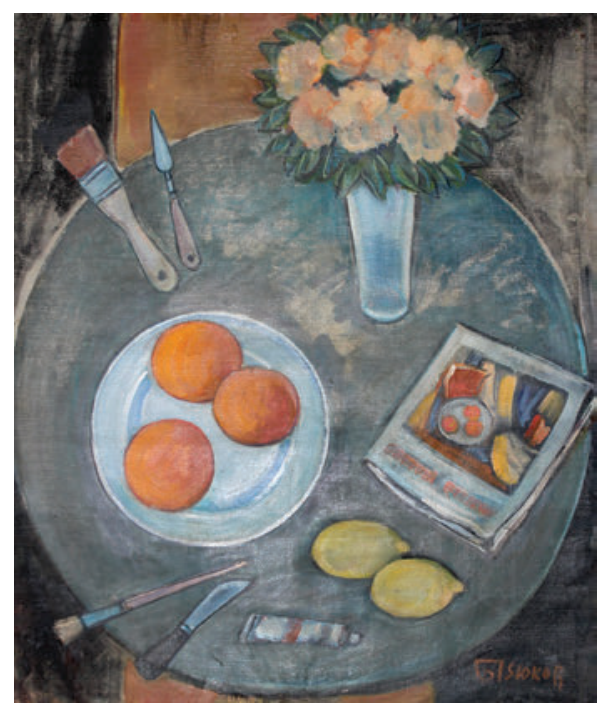

Рис. 4.3. Онуфрій Бізюков. Натюрморт на круглому столі, 1960-ті. Полотно, олія.

Fig. 4.3. Onufriy Bizyukov. Still Life at the Round Table, 1960-s. Canvas, oil.

Тут саме час згадати про друге значення слова «предметність». Бізюковим керує реальне для митця бажання - вдосконалюючи форми, «добратися» до суті змісту. Така одна з кращих його картин «Натюрморт художника» (1960-ті). Світ майстерні митця, його лабораторії роздумів і втілень, засобів у ній зведено до зображального знака - чіткого й місткого, як мистецька команда. У самій лаконічності живе дух вільного широкого - руху.

В останніх напівабстрактних полотнах художник збільшив формат, динамізував застиглий простір... Так, у «Натюрморті на стільці» (1960-ті), мазок фарби часто є лише слідом раніше непорушних форм. Зовні активний жест інколи веде й до метушливості. Але в кращих рішеннях вічною стає лише динаміка. Округле дно стільця - абстрактна крива - знак руху. У творчості цього, мабуть, найменш залежного від безпосередньої живої емоції мистця настійливо звучить специфічна нота: суміш затишку й самотності. Особлива пропорція самотності й відкритості. Мотив самостояння у просторі. Поєднання камерного й епічно вічного. Цим пройняте малярство Онуфрія Бізюкова.

У картині «Подвір'я. Мати з дитиною» (1967) втілено глибоку сутність, - здавалося б, перед нами станковий твір, але тут $€$ монументальне начало, присутні пластика, вагомість і матеріальність. І врешті-решт ці риси далі поширюються й охоплюють цикл пейзажів, такі як «Дніпро і кручі», «Вогні Дарниці», «Вечоріє» (1960-ті) серію «Трипільських вечорів» й інші. У них завжди знаходиш щось нове, якесь космічне значення природи; у невеликих полотнах, враження безмежності природних просторів. Попри це, у творах зберігається матеріальність, вагомість і багата фактурність, що буквально пронизує ці композиції, якимось чином зливаючись з могуттю пластики, яка вирізняє твори Онуфрія Бізюкова. Його краєвиди поетичні в глибокому 
Деміург: ідеї, технології, перспективи дизайну № 2 (2018)

Demiurge: ideas, technologies, perspectives of design № 2 (2018)

симфонічному плані і завжди вдало побудовані; це творіння бахівського плану...

Названі тенденції можна помітити і в натюрмортах. 3 них дві, три роботи є справжніми шедеврами! Таким є «Натюрморт з голубою скатертиною» (1960) із зібрання Полтавського художнього музею, де поєднання сірого із синім є вельми виразним, сказати б, музичним і в той же час строгим. Напрочуд вдалим поєднанням геометризації форм та насичено-яскравого колориту є однотипні натюрморти - «Оранжевий глек» (1963-1967) з колекції Національного художнього музею України і «Натюрморт з червоним глеком» (1967) з приватної збірки. Як перший, так і другий побудовані як у кольорі, так і за формою лінійно. Червоний колір має духовний полюс, недарма його пов'язують із Великою Жертвою (кров Христова), з любов'ю, життєдаруванням, формотворчістю зновународжених, оновленням і розквітом природи.

У першому натюрморті оранжево-червоний колір виступає як духовна константа. Можна вважати його нейтральним, бо він належить скоріше транспсихічній реальності як життєвий принцип дихання світу та окремої істоти, людини також. Натомість у другому - криваво-червоний є символом плотського, пекельного у світі та в людині.

| все-таки, розглядаючи енергію кольору як статус свідомості Бізюкова, не треба забувати, що тільки його гармонія з формою здатна творити духовне мистецтво. Бо форма як еквівалент духу перша з'являється ментальному зору митця, і саме вона сприймає, вбирає у себе гармонію. Тому що форма і дух співвідносяться в природі, людині, мистецтві за законом золотого перетину, де більша частина належить духу, а менша (форма) повинна відповідати гармонії задля збереження краси як блага. Але головне те, що поза формою колір втрачає потужність сакральної енергії, тому у Бізюкова він завжди розміщується строго геометрично, по формі! Ці принципи, що сповідував у своїй творчості художник, підкреслені й М. Бойчуком: «... без форми гармонійної, натхненної золотим Числом, - колір знесилює сам себе, бо зникає шлях від земного до небесного та навпаки» (Протас, 1997, с. 75).

Варто також відзначити «Натюрморт $з$ помаранчами» (1964) - один з кращих українських натюрмортів цього часу. За культурою кольору і монументальністю вирішення, а також за силою виразності - це твір високого мистецького ґатунку.

Натюрморти Бізюкова різняться між собою за конструктивністю, колоритом і багатьма іншими засобами художньої виразності. Адже створені вони в різний період. Натюрморти кін. 50-х - 60-х рр. минулого століття заслуговують особливої уваги, оскільки в них втілились відроджені засади малярства художників-бойчукістів першої третини XX століття. На обговоренні персональної виставки творів О. Бізюкова Т. Яблонська сказала: «Я його близько знаю, ми з ним сусіди, часто розмов- 
ляємо про мистецтво, і мене вражають його серйозні і глибокі знання історії мистецтва. Він великий знавець раннього італійського живопису, сучасного французького, причому знає дуже глибоко, фундаментально, добре аналізує ці твори, знає техніку виконання всіх італійських майстрів. В основі його картин лежить велике філософське розуміння мистецтва, і це завжди в ньому вражає, коли з ним розмовляєш» (Стенограми Засідань, б. р., с. 54).

Відомо, що Бізюков ретельно вивчав давньоруські фрески, які певною мірою і вплинули на його малярство. Особливо це відбилося у низці творів 1960-х рр. Майже в усіх роботах Онуфрія Терентійовича наявна м'яка, живописна площина, вона огортає всю внутрішню поверхню полотна. Він завжди глибоко розумів завдання побудови картини, його творчість базується на глибинному знанні основ світового мистецтва. Полотна О. Бізюкова відзначаються площиною широтою живопису, в якій багато світла. Вражає м'якість живопису митця; наприклад, пейзаж з вербами «Дорога до села» (1977) - дивовижне поєднання тонко віднайдених кольорів - коричнево-рожевого, зеленого, сірого і попелястого...

У його пейзажах впізнається саме українська природа, рідна земля у мистця поетична, тепла, якась саме весняна. Манера письма художника врівноважена: кожне його полотно живе своїм спокійним життям.

Як уже зазначалося, чимало пейзажів Бізюкова за розміром невеликі, але у них присутній огляд масштабного світу, відбито великий світ на маленькому шматочку. Володіючи безперечним даром колориста і тонко відчуваючи найменші зміни настрою природи, майстер створює пейзаж, пройнятий гармонійним музичним ритмом та ліризмом.

Багато уваги митець приділяє близькості людини до природи; злитості переживань людини і стану природи, ніби розчиненню у ній. Картина «Зима» (1960-ті) - це широкий, енергійний мазок, локальний колір, несподіваність композиції, декоративність живопису... Свої емоції, свій контакт з природою Бізюков передає в гранично напруженій колірній гамі; сприймає світ у нестримному русі, котрому підпорядковує форму і колір. Структура його полотен не порушує канонів ритмічної організації композиції, а декоративність поглиблює відчуття гармонії. Скільки почуття в рухливих синіх, червоних, фіолетових соковитих мазках, що ними виліплено сніг і дерева, передано настроєвість! У полотні «Татарка» (1965) улюблені кольори майстра блакитний і фіалковий - оспівують чарівність зими.

Віталій Ханко під враженням від творів художника зазначав: «О. Бізюкову властиве тонке відчуття кольору, композиційна майстерність, вміння відкривати красу природи навіть у найпростіших їі проявах. Джерела його натхнень та захоплень народне мистецтво, з особливою увагою до його властивих 
Деміург: ідеї, технології, перспективи дизайну № 2 (2018)

Demiurge: ideas, technologies, perspectives of design № 2 (2018)

пластичних засад (основ). О. Бізюкову властива - внутрішня закінченість, аж ніяк не зовнішня» (Бізюков, б. р., с. 20).

Палітра О. Бізюкова багата на тонкі градації відтінків у межах кожного з обраних ним кольорів. Він ефектно використовує найскладніші прийоми вальорного живопису у творах: «Моя мансарда» (1947), «Влітку» (1950), «Дніпро і кручі» (1957). Колористичну і композиційну організацію кращих полотен художника можна без перебільшення назвати бездоганною.

Багатство творчих інспірацій Онуфрія Бізюкова лягло в основу чи не найбільшої його серії оголених жіночих образів.

У цей час в художника відбуваються деякі трансформації у трактуванні образу жінки. Якщо раніше Бізюков зображував жінку переважно за роботою або на нейтральному тлі - це здебільшого були конкретні люди або збірний образ-враження без конкретизації особистих рис, то тепер він створює універсальний образ, «універсальний» у сенсі космічному. Жінки у Бізюкова не схожі ні на кого і водночас схожі на всіх. До нас дійшла велика серія ню - споконвічного жанру в історії мистецтва, що відтворював оголене людське, переважно жіноче, тіло чи якісь його частини та їхні інтерпретації. Бізюков розвивав теми оголеної жіночої моделі, не полишаючи жанрів автопортрета і натюрморту.

Пленерні здобутки цього періоду змінили оптику Бізюкова, вона стає вивільненою. Так з'являються нові образи, які до того не фігурували у творчості художника. Дедалі абстрактнішим, особливо на початку 1960-х рр. стає тло композицій, все більш лінеарно вирішує Бізюков свої ню. Одночасно переносить їх з малоформатних аркушів паперу на великі. У цей період він студіював різні стани моделі, пози, варіював конструктивність побаченого, урізноманітнював форму та композицію. У численних варіаціях «ню» він то гранично наближується до натури, то віддаляється від неї.

Зустрічаються портрети різних планів: погрудні, поясні, на повен зріст, лежачі постаті та багатофігурні композиції. Бізюков шукав вирішення форми, яка б найбільш точно, лаконічно відповідала смисловому наповненню.

Жіночі образи Бізюкова часто стають уособленням природних сил. Композиція «Амазонки біля човна» (1960-ті) є тому яскравим прикладом. У цьому випадку синій колір перебуває у потенціалі, він є тим тлом, на якому відбиваються всі інспірації художника. У природі, що і підтверджує синій твір, цей колір пов'язаний зі стихіями (вода, повітря), він супроводжує магнетичні ефекти напруги, що в структурі твору $є$ ніби випромінюванням лептонного поля, яке мерехтить іскрами психолофізіологічних імпульсів; і все це нашаровується на ключовий колір полотна 3 його тяжінням до зелено-червоного та індиго-зеленого.

Ці образи можемо співвіднести з містифікованими образами українського фольклору: русалками та мавками, можна накласти на образи Бізюкова, і вони будуть гармонійні. Русалки на- 
прочуд ніжні і сумні, часто зовсім оголені, вони нагадують образи купальниць Бізюкова, інші схожі на мавок - жительок лісових хащів і полів. Художник свідомо чи інтуїтино поєднує в таких образах архаїчні мотиви з модерними бойчуківськими. (Рис. 4.4).

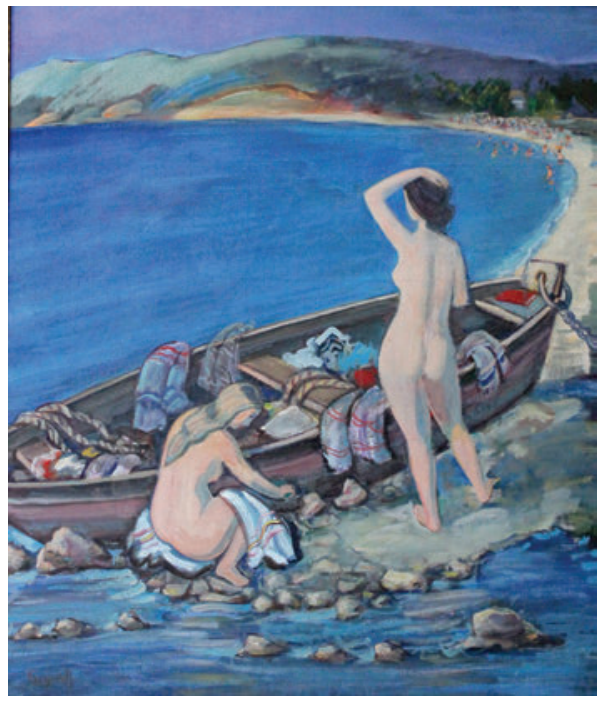

Рис. 4.4. Онуфрій Бізюков. Амазонки біля човна, 1960-ті. Полотно, олія.

Fig. 4.4. Onufriy Bizyukov. Amazon by the boat, 1960-s. Canvas, oil.

Міфологізація образу оголених у Бізюкова часто апелює до архетипу Матері-Землі - богині землі, яка колись вважалася святою. Образ Землі-Матері сягає глибокої давнини - щонайменше до праіндоєвропейської епохи. Про це свідчать численні паралелі цього персонажа в міфології індоєвропейських народів: Деметра в грецькій, Анаїта в іранській, Жеміна в литовській та ін. Ріки, моря і землі втілені у Бізюкова у досить реальних жіночих образах. Опісля своє жіноче втілення отримують і абстрактні поняття: пробудження, сон. Часто художник розміщує жінку на всій площині полотна, її тіло майже закриває його. Залишаються лише невеликі частини тла, які очевидно є землею, небом і водою. Такою є «Оголена на пляжі» (1960-ті) (Рис. 4.5).

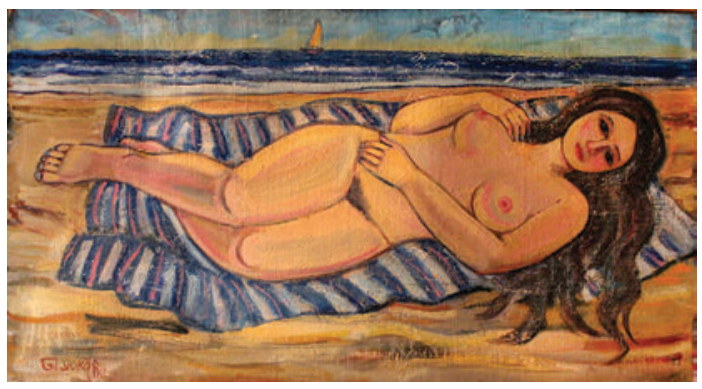

Рис. 4.5. Онуфрій Бізюков. Оголена на пляжі, 1960-ті. Полотно, олія.

Fig. 4.5. Onufriy Bizyukov. Nude on the beach, 1960-s. Canvas, oil.

Окремі жіночі образи Бізюков ототожнює із силами природи, хоча вони неодмінно антропоморфні, жодного абстрактного зображення не знайдемо у мистецтві художника, хоч і трапляються стилізації в дусі неопримітивізму у творенні образу моделі. 
Деміург: ідеї, технології, перспективи дизайну № 2 (2018) Demiurge: ideas, technologies, perspectives of design № 2 (2018)

В образи оголених митець вкладав щось значно більше, аніж оспівування селянок-колгоспниць та їхньої праці, як це часто можна зустріти у заідеологізованій творчості тогочасних художників.

Твір «Українська Венера» (1960-ті) - це уособлення молодої Землі, що пробуджується, своєрідний аналог весняної пори, пробудження України.

Очевидно, що тема Землі постійно хвилює митця і постійно повертає його саме до такого персоніфікованого трактування. Із землі, згідно з Біблією, апокрифами і народними легендами, створено тіло людини: душа ії після смерті потрапляє у верхній світ, а тіло - в землю. Людина постійно і неодмінно пов'язана із землею. Земля, за слов'янською традицією, є символом материнства і жіночого начала. Ось ці риси і знаходимо у творчості Онуфрія Бізюкова, він наче шукає правильний варіант, вірну відповідь на питання, що таке земля. I не зупиняється на чисто формальному рівні, а підноситься на метафізичний.

Таким чином, період відлиги в образотворчій культурі загалом, як і у творчості Бізюкова зокрема, став ще одним маркером на шляху до подальшого творення й урізноманітнення образу жінки. Це час експериментів і пошуків, відкриття нового, що Бізюков робив безстрашно. Це диктувалося не лише внутрішнім голосом і потягом до нового або відродженням ідей бойчукізму, а й історичними й культурними умовами, що склалися на теренах України в 60-ті роки минулого століття. Ці часто несприятливі умови активізували цілу плеяду митців, які почали шукати адекватних форм вираження, не зраджуючи в той самий час власних принципів і традицій. Так чинив і Бізюков, маючи за плечима великий життєвий і творчий досвід, заглиблюючись в історію мистецтва різних народів, а особливо давньоукраїнського. Він почав розвивати власні ідеї, які згодом утілились у низці живописних та графічних творів, а окрім того, в маловідомих, але суттєво важливих мистецтвознавчих дослідженнях та есеях.

Як сказав хтось із класиків, «від кохання до жінки народилося все найпрекрасніше у світі»! Це було також і важливою темою у творчості Онуфрія Бізюкова. Будучи неодруженим талановитим митцем, він мав багато шанувальниць та прихильниць. Про це свідчить хоча б така проста річ: на багатьох полотнах зображені оспівані ним оголені жіночі постаті. Їх безліч!

У радянський час художник жив скромно, тому не міг собі дозволити оплачувати кожній натурниці їі працю. А полотен з них написав чимало. Їм усім він був вдячний. Натурниці йшли на великий ризик, адже більше 50-ти років тому в людей була інша психологія. Малювання оголеної натури, навіть не в інституті, а так, приватно... й уявити собі не можна, чим це могло обернутися!

Бізюков фіксує різні жіночі образи. Це і дівчата школярки, і його сусідки по майстерні, подруги, натурниці, знайомі... 
Усі вони різні і передають відповідний характер зображуваної. Художник не слідує усталеній визначеній манері чи техніці, для кожного образу він підбирає особливу лінію, штрих, матеріал, частіше колір, які формують своєрідний образ. Деякі з них просто є узагальненим - вигаданим і сформованим в уяві образом жінки. Робота у різних техніках відкриває різнобічність бачення митця. В основному це твори, виконані акрилом, олією, пастеллю або ж олівцем.

Моделі самі знаходили художника, переважно через подруг, яких Бізюков уже малював. Вони погоджувалися позувати безкоштовно. Дівчат заворожувала спокуса мати малюнок або живописний етюд оголеної себе. Малював Бізюков своїх «ню» найчастіше на березі річки, моря, на камінні, скелі, в майстерні, інтер'єрі, на підвіконні, в ліжку, умовному просторі... Так, на полотні «В майстерні» (1960-ті) Бізюков представив глядачеві жінку, що сидить на умовному подіумі з широко розведеними ногами, показуючи лоно. У формуванні композиції автор використовує лише три кольори та їхні переходи: синій, вохру та рожевий відтінок; додаючи до них білила і змішуючи, художник творить інші кольори. Проте вони вже покладені локальними плямами на полотні і грають з лінією, яка формує силует. Автор дивиться на жінку ніби згори вниз, тому лінія горизонту знаходиться над нею, вона повністю входить у сферу земного, стає з нею одним цілим.

Характерні, витончені, граційні, кокетливі, просякнуті чуттєвістю оголені на полотнах Бізюкова заворожують глядача загадковістю, пристрасністю та глибиною. Його купальниці нагадують образи дівчини-ріки, вони ніби матеріалізуються в просторі, не втративши при цьому ні легкості, ні прозорості. Так, «Оголена з рушником» (1960-ті) - молода симпатична чорнява дівчина дивиться просто на глядача, тримаючи рушник. Чітко вимальовуєються тендітна шия, оголені плечі, обрис грудей, і все тіло, - плавні й заокруглені форми створюють елегійний образ. Обличчя спокійне та натхненне. Примітивна в своїй основі лінія вимальовує усю постать. Лаконічна форма, впевнена поза презентують глядачеві жінку у солодкій знемозі.

Справжньою родзинкою серед ню автора $€$ «Оголена на скелі» (1960-ті), - приклад майстерного відчуття форми і кольору. Переважають ніжні, рожеві відтінки, мазок широкий, рельєфний, одним порухом художник окреслює площини обличчя, водночас узагальнюючи образ, зводячи його до якогось універсального відтворення жіночого образу. Інші його зображення оголених моделей теж, в основному, побудовані на зіставленні трьох-чотирьох основних кольорів і головне, домінуючої неопримітивної лінеарності, що була основою у творчості художників-бойчукістів у 1920-ті - 1930-ті рр.

Автор залишає частини картини не прописаними, за рахунок цього активно працює колір, переважають темні відтінки: червоні, сині, чорні та вохристі... Художник з великою майстер- 
Деміург: ідеї, технології, перспективи дизайну № 2 (2018)

Demiurge: ideas, technologies, perspectives of design № 2 (2018)

ністю передає композиційну площинність, наносячи контури обличчя шляхом продряпування на поверхні фарби.

Інша композиція - «Лежача із човном» (1960-ті) - вирізняється своїм конструктивним вирішенням. Тут Бізюков оперує лінією: впевнено і чітко будує контур, одні лінії більш інтенсивні, інші стають усе прозорішими, накладаються одна на одну, за рахунок чого створюється своєрідна ілюзія глибини простору в рисунку. Здається, якби Бізюков залишив лише лінію, то образ все одно б читався. Пропорції тіла не є правильними, у купальниці поза і вигини тіла дещо незграбні й незручні. Ця композиція слугує яскравим свідченням звернення Бізюкова до основних засад бойчукізму, а саме - конструктивності образотворчого мислення. Нагадаємо, це відбувається у 1960-ті роки, в період «відлиги».

Серія «Жінки-Моря» Онуфрія Бізюкова, де митець здійснив своєрідне об'єднання морської стихії з жіночими образами, вражає багатством лінеарної культури. 3 одного боку, витонченість лінії та їі стриманість на абстрактному однотонному тлі, - натомість з іншого, - з'являється одна тонка безперервна лінія, яка формує завершені образи дівчат на заповненій плямами та мазками фарби колірній основі. Жінки на полотнах Бізюкова цієї серії - стародавні архетипи жіночності - тонуть в колірних морях, уособлюючи материнську та жіночну красу, що вийшла з глибини несвідомого. Така інтерпретація цікава, бо, справді, в роботах дівочий образ, здається, розчиняється у написаних хвилях, проте чи дає це легкість, чи дійсно дівчата схожі на силу природи?

Візьмемо до прикладу роботу «Замислена» (1960-ті) - цікаво Бізюков використовує колір, тіло оголеної переливається барвами, синюваті, фіолетові і рожеві тони перехлюпуються у золотаві відтінки помаранчевого і жовтого кольорів. Поверх цієї гри фарб художник тонкими, а подекуди грубими лініями прокладає штрихи, що відтворюють морські хвилі.

В окремих «ню» художник втілює відвертість еротизму, немовби промовляючи до глядача: «Покажіть мені свою еротику, і я скажу, хто ви...». Оголене жіноче тіло на пом'ятих простирадлах, «ню» з рушниками у руках та на плечах, під час споглядання, за туалетом, розчісуючи волосся і ще безліч таких варіацій - репрезентація самого жадання, самого потягу... У інших композиціях Бізюков трактує жінку як щось пасивне, покірне, м'яке, згідливе. Тобто він підбирає до кожної відповідний образ, передає її настрої та психологію натури.

у багатофігурних зображеннях оголених на пляжі митець ніби презентує в одному просторі різні погляди на еротику, переосмислює своє уявлення про еротичне і про жіноче тіло загалом. Парадокс: деякі живописні жіночі зображення здаються майже нав'язливими, хоча й варіативними повтореннями, ніби художник використовує кілька дуже інтимних образів раз по раз, намагаючись чи то вдосконалити, чи то позбутися їх.

Картини з оголеними жіночими постатями Бізюков лише зрідка виставляв на тогочасних виставках, бо вони випадали із 
загального контексту. Тим важливішим є сьогодні простежити за вибудовуванням Бізюковим логіки історичних видозмін цих образів, відносин художника до жінки, пошук витоків їх у далекому й недалекому минулому.

Онуфрій Терентійович Бізюков відійшов у вічність 15 березня 1986 року в Києві, у віці 88-ми років. На якому кладовищі він похований, не вдалося встановити й досі. Малярська й теоретична спадщина художника збереглася в українських музеях, більша її частка - в закордонних та національних приватних колекціях. Завдяки дбайливому плеканню творів Бізюкова окремими збирачами, сьогодні ми маємо змогу ознайомити широке коло поціновувачів мистецтва з творчістю видатного художника-бойчукіста авангардного спрямування.

Визначення «бойчукіст» або «націоналіст», яке було тоді принизливим тавром, переслідувало учнів Учителя все життя, ламаючи долі, не даючи ні творити, ні спокійно жити. Деякі бойчукісти встигли виїхати з України, загубилися, «розчинилися», але продовжували працювати, не зраджуючи себе. Проте до кінця 1980-х рр. їхні картини на теми праці простих робітників взагалі забороняли показувати - не вписувалися в рамки соціалістичного реалізму (Володимирова, 2017).

Коли розглядаєш твори, вивчаєш долі художників, приходить розуміння: якого рівня могло б досягнути українське мистецтво, як би бойчукісти вільно творили, втілюючи в життя засади Учителя! Вражають сміливість задумів, самовідданість, з якою вони бралися за їх утілення. Це були однодумці, талановиті митці, які прагнули сказати нове слово і втілити свої новаторські ідеї в образотворчому мистецтві, глибоко закорінюючись у національний ґрунт.

\section{Наукова новизна та практичне значення дослідження

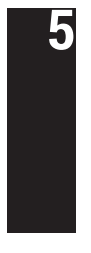

Отже, Онуфрій Бізюков зумів полюбити Україну як рідну Батьківщину, полюбити ії людей, традиції, культуру, мистецтво... Саме їм він присвятив усе своє життя, починаючи ще з навчання у Миргороді. Художник на початках творчого злету, розвивався у кубістично-примітивістському ключі, проте комуністична система надламала його мистецький потенціал. I не тільки його!

О. Бізюков спричинився й до розвитку музейництва; його діяльність також дала пагіння у педагогічному напрямі, зрештою, він був і художником-монументалістом, що заявив про себе як учасник перших масштабних розписів у Європі XX століття. Він долучився до розвитку пейзажного живопису України того самого часу, розвиваючи імпресіоністичні тенденції у цьому жанрі.

Проте головна його роль полягала в тому, що, незважаючи на всі труднощі життя, Бізюков зумів зберегти і розвинути традиції бойчукізму у другій половині XX століття, передаючи естафету талановитій молоді. Він, як останній з могікан-хранителів, заповідав майбутній плеяді настанови Бойчука, бо сам завдяки Учителю долучився до розвитку європейського культурного процесу того часу. 
Деміург: ідеї, технології, перспективи дизайну № 2 (2018)

Demiurge: ideas, technologies, perspectives of design № 2 (2018)

Висновки 6 Мистецтво бойчукістів стало одним із вершинних досягнень культурного відродження 20-х - поч. 30-х років минулого століття. Але батько і засновник цієї течії Михайло Бойчук був приречений на загибель як «противник» тогочасної ідеологічної системи. Так і сталося... Після довгих допитів НКВС йому і найближчим соратникам сфабрикували справи і засудили до найвищої міри покарання. М. Бойчука, І. Падалку, В. Седляра, І. Липківського, С. Налепинську-Бойчук, Є. Ситнянського було розстріляно 13 липня, зловісного 1937 року. А через рік і М. Касперовича. Доля решти учнів М. Бойчука складалася по-різному, але в усіх виявилась нелегкою...

Саме завдяки творчій самовідданій праці «бойчукістів», Україна в 20-ті - 30-ті роки XX століття була в авангарді світової культури. Учні Бойчука, що дивом залишились живими, бережливо плекали і розвивали шляхетні творчі засади Учителя, передаючи їх майбутнім поколінням, художникам т. зв. «четвертої хвилі». Сьогодні це - відомі, талановиті художники-монументалісти: Петро Гончар, Ніна Денисова, Микола та Петро Малишки, Олександр Мельник, Володимир Федько (1940-2006). Значною мірою засади бойчукізму у своїй школі монументального малярства використовував академік Віктор Гонтарів (1943-2009) з Харкова.

\section{Список посилань}

Бізюков, О. (б. р.). Коротка автобіографія [Рукопис]. Архів С. Білоконя.

Володимирова, В. (2017). Школа Михайла Бойчука. Взято з http://zv.zp.ua/articles/1032SHkola-Mihayla-Boychuka.html.

Протас, М. (1997). Сакральна енергія кольору як статус самосвідомості мистця. Образотворче мистецтво, 1, 73-75.

Разінкіна, О. (2002). “... Колір здатний говорити сам”. Образотворче мистецтво, 2, 24.

Стенограми засідань СХ УРСР щодо обговорення робіт Бізюкова та виставки його творів. (б. р.). (Фонд 634, Опис 1, Справа 14). Центральний державний архів-музей літератури і мистецтва України, Київ.

\section{References}

Biziukov, O. (n. d.). Korotka avtobiohrafiia [Rukopys] [Short autobiography [Manuscript]]. Arkhiv S. Bilokonia [in Ukrainian].

Protas, M. (1997). Sakralna enerhiia koloru yak status samosvidomosti mysttsia [Sacred energy of colour as the status of the artist's self-consciousness]. Obrazotvorche mystetstvo, 1, 73-75 [in Ukrainian].

Razinkina, O. (2002). "...Kolir zdatnyi hovoryty sam" ["...The colour can speak"]. Obrazotvorche mystetstvo, 2, 24 [in Ukrainian].

Stenohramy zasidan SKh URSR shchodo obhovorennia robit Biziukova ta vystavky yoho tvoriv [The transcripts of the meetings of the USSR UA concerning the discussion of Bizyukov's works and exhibitions of his works] (n. d.). (Fund 634, Inventory 1, File 14). Central State ArchiveMuseum of Literature and Art of Ukraine, Kyiv [in Ukrainian].

Volodymyrova, V. (2017). Shkola Mykhaila Boichuka [School of Mykhailo Boychuk]. Retrieved from http://zv.zp.ua/articles/1032-SHkola-Mihayla-Boychuka.html [in Ukrainian]. 